\title{
Perototipe Knowledge Management System Untuk Mendukung Proses Pembelajaran Dengan Pendekatan Seci Dan Desain Mvc
}

\author{
Aso Sudiarjo $^{1}$, Aries Kusdaryono ${ }^{2}$ \\ ${ }^{1}$ Univeristas Perjuangan Tasikmalaya, Jl. Peta No.177, Kota Tasikmalaya, 46115, Indonesia \\ ${ }^{2}$ Universitas Budi Luhur, Jl. Ciledug Raya, Pertukangan Utara, Jakarta Selatan, 12260, Indonesia
}

\section{INFORMASI ARTIKEL}

Sejarah Artikel:

Diterima Redaksi : -

Revisi Akhir : -

Diterbitkan Online : -

\section{Kata Kunci :}

Knowledge Management System, SDM, SECI, MVC Desain, Focus Group Discussion, ISO 9126,

\section{Korespondensi :}

Telepon / Hp : +6285288614535

E-mail : asosudiarjo@unper.ac.id

\section{A B S T R A K}

\begin{abstract}
Perkembangan kebutuhan informasi juga sejalan dengan berkembangnya ilmu pengetahuan dan teknologi yang sangat pesat diantaranya dalam dunia pendidikan. Penerapan Knowledge Management di institusi pendidikan salah satunya di pondok pesantren nampaknya sudah menjadi suatu kebutuhan mendasar pada era globalisasi ini. Masih Banyak Institusi pendidikan seperti pondok pesantren yang belum memiliki sarana dan prasarana teknologi informasi untuk menyimpan, bertukar pengalaman(tacit), informasi dan pengetahan (knowledge) untuk meningkatkan kualitas sumber daya manusia (SDM) di sekolah yaitu guru, untuk itu dibutuhkan knowledge management yang baik, transfer knowledge yang dilakukan oleh guru-guru masih terbatas dalam forum rapat belum ada dokumentasi atau teknologi yang menyimpan tacit dan knowledge guru-guru yang berpengalaman dalam mengajar. Knowledge Management System (KMS) merupakan solusi ideal untuk mengembangkan dan meningkatkan budaya saling berbagi knowledge (sharing knowledge) antara individu maupun organisasi. Pada penelitian ini, penulis mencoba mengembangkan model knowledge management system sesuai dengan kondisi yang ada di MA Madinatunnajah pada Pondok Pesantren Madinatunnajah dengan menggunakan model SECI dalam pembentukan knowledge dan untuk analisa struktur dan desain aplikasi dengan Desain MVC. dan pengujian validasi dengan Focus Group Discussion (FGD) dan untuk pengujian Kualitas perangkat lunak dengan mengadopsi ISO 9126. Dari hasil penelitian ini adalah sebuah prototipe knowledge management system yang dapat diaplikasikan di MA Madinatunnajah sebagai solusi dalam mendukung proses pembelajaran. Berdasarkan hasil pengujian dengan Focus Group Discussion (FGD) memiliki nilai tanggapan baik dan diterima, serta pengujian kualitas prototipe dengan mengadopsi ISO 9126 dapat disimpulkan bahwa persentasi kualitas prototipe perangkat lunak KMS dengan kategori baik.
\end{abstract}

\section{PENDAHULUAN}

Perkembangan kebutuhan informasi juga sejalan dengan berkembangnya ilmu pengetahuan. dan teknologi yang sangat pesat diantaranya dalam dunia pendidikan, dan kita ketahui perkembangan ilmu pengetahuan dan teknologi dapat memberikan banyak kemudahan dalam pengelolaan pengetahuan atau knowledge management dari suatu instansi pendidikan. Fungsi informasi tidak hanya sebatas pertukaran pesan saja, tetapi merupakan kegiatan individu dan kelompok dalam tukar menukar data, fakta serta ide - ide. Dengan pesatnya teknologi informasi maka harus diiringi dengan sumber daya manusia (SDM) yang berkualitas dan kompetitif. Sumber daya manusia merupakan salah satu faktor terpenting dalam sebuah instansi pendidikan, dimana knowledge yang dimiliki setiap sumber daya manusia tersebut merupakan aset bagi instansi pendidikan yaitu sekolah. Dalam meningkatkan kualitas sumber daya manusia (SDM) khususnya SDM di sekolah yaitu guru maka dibutuhkan knowledge management yang baik pula.

Pondok Pesantren Madinatunnajah adalah lembaga pendidikan Islam yang menyelenggarakan program pendidikan yang berjenjang mulai dari pendidikan pra sekolah sampai ke pendidikan tinggi,
Kurikulum yang digunakan adalah perpaduan antara kurikulum pendidikan pesantren dengan kurikulum pemerintah. Sehingga lulusannya dapat melanjutkan ke jenjang pendidikan yang lebih tinggi, baik di dalam maupun luar negeri.,

Sedangkan permasalahan yang timbul saat ini yaitu belum adanya fasilitas sekolah untuk menunjang guru dalam bertukar data, pengalaman (tacit), informasi, pengetahuan dan bahan ajar. Transfer knowledge yang dilakukan oleh guru-guru masih terbatas dalam forum rapat belum ada dokumentasi atau media teknologi untuk menyimpan tacit dan knowledge guru-guru yang berpengalaman dalam mengajar.

Untuk mengoptimalkan sharing dan transfer knowledge di Madrasah aliyah (MA) madinatunnajah pada Pondok Pesantren Madinatunnajah perlu adanya sebuah system pengelola pengetahuan atau biasa disebut knowledge management system. Dengan memanfaatkan teknologi informasi penulis berupaya mengajukan solusi sebuah prototipe knowledge management system yang sesuai dengan kebutuhan Pondok Pesantren Madinatunnajah sebagai upaya untuk meningkatkan proses kegiatan pembelajaran lebih efektif, serta membantu menyelesaikan permasalahan yang ada pada Pondok Pesantren Madinatunnajah. 
Berdasarkan identifikasi masalah di atas, maka permasalahan yang akan dijawab yaitu : "Bagaimana model knowledge management system yang sesuai di MA madinatunnajah pada Pondok Pesantren Madinatunnajah untuk mendukung proses pembelajaran?"

\section{LANDASAN PEMIKIRAN}

\subsection{Konsep Dasar Knowledge Management System}

Knowledge management system adalah integrasi antara teknologi dan mekanisme yang dibangun untuk mendukung proses knowledge management[2]. Istilah knowledge management system merujuk pada sekelompok system informasi yang diaplikasikan untuk mengelola pengetahuan organisasi. Knowledge managemen system adalah sistem berbasis teknologi informasi yang dikembangkan mendukung dan meningkatkan proses organisasi dari penciptaan, penyimpanan, transfer dan aplikasi pengetahuan menurut Butler [4].

Knowledge terbagi menjadi dua jenis yaitu Explicit Knowledge dan Tacit Knowledge yang dapat dijabarkan sebagai berikut :

1. Explicit Knowledge

Konten yang telah ditangkap dalam beberapa bentuk nyata seperti kata-kata, rekaman audio, atau gambar[5].

Knowledge jenis ini dapat segera diteruskan dari satu individu ke individu lainnya secara formal dan sistematis. Knowledge ini juga dapat dijelaskan sebagai suatu proses, metode, cara, pola bisnis dan pengalaman desain dari suatu produksi.

\section{Tacit Knowledge}

Sulit untuk diungkapkan ke dalam kata-kata, teks, atau gambar[5]

Knowledge ini bersifat sangat personal dan sulit dirumuskan sehingga membuatnya sangat sulit untuk dikomunikasikan atau disampaikan kepada orang lain. Perasaan pribadi, intuisi, bahasa tubuh, pengalaman fisik serta petunjuk praktis termasuk dalam knowledge ini

\section{Knowledge Management System}

Peran teknologi informasi sangat besar terhadap knowledge management. Teknologi informasi menjadi sebuah "enabler" bagi terjadinya proses-proses yang terdapat dalam knowledge management. Dengan adanya teknologi yang ada seperti jaringan, perangkat keras dan lunak, proses penyebaran knowledge dari karyawan satu dengan karyawan yang lain bisa dilakukan dengan mudah. Ada dua pendekatan dalam melihat peran teknologi informasi ini, yaknii kodifikasi dan personalisasi [6]. yaitu sebagai berikut :

1. Kodifikasi

Kodifikasi adalah terkait dengan penyimpanan knowledge. Salah satu peran teknologi informasi dalam mendukung knowledge management adalah melalui pembuatan database untuk explicit knowledge yang ada dalam suatu organisasi, sehingga knowledge tersebut dapat diambil dan digunakan dengan mudah.

2. Personalisasi

Penerapan knowledge management yang berbasis teknologi informasi bukan hanya sekedar menyimpan knowledge yang ada saja akan tetapi juga bagaimana menghubungkan antara satu orang dengan yang lain. Biar bagaimanapun orang akan cenderung untuk berkomunikasi dengan orang lain dahulu sebelum benar-benar mencarinya di database. Untuk itu harus disediakan juga fasilitas yang dapat memudahkan proses komunikasi ini seperti diskusi elektronik, e-mail.

\subsection{SECI Model}

Nonaka memberikan suatu model yang menunjukkan suatu daur dalam Knowledge Management. Daur ini terdiri atas 4 tahapan yang dikenal dengan nama SECI sepeti gambar dibawah ini :

\begin{tabular}{|l|l|}
\hline Sosialisasi & Eksternalisasi \\
Tacit $\rightarrow$ Tacit & Tacit $\rightarrow$ Explicit \\
\hline Internalisasi & Kombinasi \\
Explicit $\rightarrow$ Tacit & Explicit $\rightarrow$ Explicit \\
\hline
\end{tabular}

Penjelasan :

Gambar 1. Model SECI

1. Socialization (Sosialisasi)

Pada tahap ini terjadi pemindahan pengetahuan yang berbentuk tacit ke orang lain. Perpindahan ini terjadi melalui komunikasi langsung karena pengetahuan ini pindah ke kepala orang lain maka bentuk pengetahuan ini masih tetap tacit. (tacit tacit) 2. Externalization (Eksternalisasi)

Pengetahuan yang berbentuk tacit dapat berubah menjadi explicit dengan mengartikan pengetahuan yang ada di kepala orang menjadi bentuk formal yang mudah dimengerti oleh orang lain (tacit explicit)

3. Determination / Combination (Kombinasi)

Pengetahuan yang berbentuk eksplicit mudah untuk dibagi. Pada fase ini pengetahuan dibagi ke berbagai orang dan memungkinkan semakin baiknya pengetahuan ini dengan adanya masukan dari orang lain. Bahkan dapat mendorong terbentuknya pengetahuan baru (explicit explicit)

4. Internalization (Internalisasi)

Pengetahuan yang telah terdokumentasi dapat diambil dan digunakan oleh orang lain untuk menambah pengetahuannya. Pengetahuan explicit ini ketika telah berada di kepala orang lain maka pengetahuan tersebut berubah menjadi tacit. (explicit tacit ).

\subsection{Konsep Dasar MVC}

Model-View-Controller (MVC) adalah sebuah konsep yang diperkenalkan oleh penemu Smalltalk(Trygve Reenskaug) untuk meng-enkapsulasi data bersama dengan pemrosesan (model), mengisolasi dari proses manipulasi (controller) dan tampilan (view) 
untuk direpresentasikan pada sebuah user interface [7]. MVC pattern terbagi menjadi 3 modul, model, view, dan Controler berikut adalah gambaran MVC pattern:

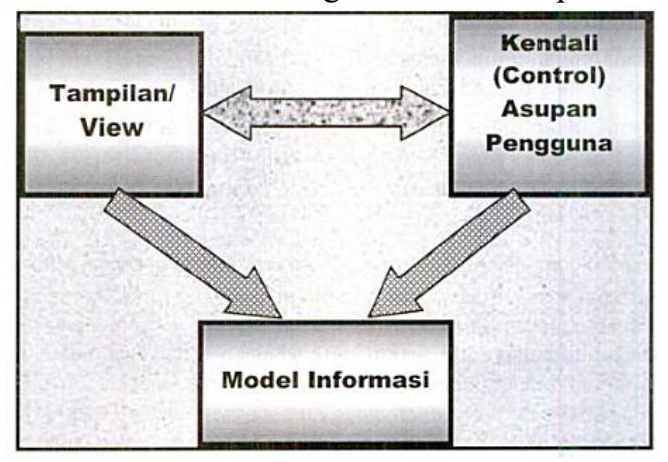

Gambar 2. Model MVC

Menurut Burbeck [3],Definisi teknis dari arsitektur MVC dibagi menjadi tiga lapisan yaitu:

Model, digunakan untuk mengelola informasi dan memberitahu pengamat ketika ada perubahan informasi. Hanya model yang mengandung data dan fungsi yang berhubungan dengan pemrosesan data. Sebuah model eringkas lebih dari sekedar data dan fungsi yang beroperasi di dalamnya. Pendekatan model yang digunakan untuk komputer model atau abstraksi dari beberapa proses dunia nyata. Hal ini tidak hanya menangkap keadaan proses atau sistem, tetapi bagaimana sistem bekerja. Sebagai contoh, programmer dapat menentukan mode yang menjembatani komputasi back-end dengan front-end GUI (graphical user interface).

View, bertanggung jawab untuk pemetaan grafis ke sebuah perangkat. View biasanya memiliki hubungan 1-1 dengan sebuah permukaan layar dan tahu bagaimana untuk membuatnya. View melekat pada model dan me-render isinya ke permukaan layar. Selain itu, ketika model berubah, view secara otomatis menggambar ulang bagian layar yang terkena perubahan untuk menunjukkan perubahan tersebut. Terdapat kemungkinan beberapa view pada model yang sama dan masing-masing view tersebut dapat me-render isi model untuk permukaan tampilan yang berbeda

Controller, menerima input dari pengguna dan menginstruksikan model dan view untuk melakukan aksi berdasarkan masukan tersebut. Sehingga, controller bertanggung jawab untuk pemetaan aksi pengguna akhir terhadap respon aplikasi. Sebagai contoh, ketika pengguna mengklik tombol atau memilih item menu, controller bertanggung jawab untuk menentukan bagaimana aplikasi seharusnya merespon

\subsection{CodeIgniter ( CI )}

Codeigniter merupakan framework php yang diklaim memiliki eksekusi tercepat disbanding dengan framework lainnya. Codeigniter bersipat opensource dan mengunakan model basic MVC ( model view controller), yang merupakan konsep modern framework yang digunakan saat ini [12].

\section{Pengujian Validasi dengan Focus Group Discussion}

Menurut Litosseliti, Focus Group Discussion adalah kelompok kecil yang terstruktur dengan partisipan yang telah dipilih dengan dipandu moderator. Focus Group Discussion ini disusun untuk tujuan menggali topik yang spesifik dan pandangan dan pengalaman individu melalui interaksi kelompok.[10]

Focus Group Discussion sebagai salah satu bentuk penelitian kualitatif yang merupakan wawancara kelompok yang ditekankan pada interaksi dan perilaku yang muncul dalam kelompok, ketika kelompok itu disodorkan suatu topic atau isu tertentu dengan kepentingan penelitian. Tujuan dari focus group discussion adalah untuk memperoleh persepsi dan sikap mengenai isu yang didiskusikan. Diskusi berlangsung secara terbuka, sehingga setiap individu yang terlibat dapat mengekspresikan pendapatnya dengan bebas dan terbuka. Alasan penulis memilih metode focus group discussion adalah agar memperoleh informasi yang akurat mengenai persepsi guru- guru di MA Madinatunnajah mengenai penerapan knowledge management.

Focus Group Discussion memiliki lima (5) karakteristik yang berkaitan dengan unsur-unsur kelompok diskusi sebagai berikut :

1. Jumlah peserta Focus Group Discussion sebaiknya empat (4) sampai dua belas (12) orang. Bila jumlah peserta kurang dari empat (4) orang dikhawatirkan anggota kelompok cepat memperoleh giliran berbicara dan tidak terjadi penggalian ide sehingga akan mengurangi keragaman dan terjadi kekuasaan ide. Jika jumlah peserta lebih dari dua belas (12) orang akan mengakibatkan diskusi sulit dikendalikan karena peserta terlalu banyak pandangan/ide.

2. Peserta mempunyai karakteristik yang homogen. Homogenitas menjadi salah satu dasar pemilihannya. peserta diskusi dipilih karena mempunyai persamaan pengalaman, profesi, gender, usia, status dan sebagainya. Disamping itu peserta mempunyai kepentingan dengan permasalahan yang akan dibahas.

3. Informasi yang diambil dalam diskusi bukan yang bersifat konsensus atau rekomendasi untuk mengambil keputusan, melainkan informasi mengenai sikap, persepsi dan perasaan pesserta yang berkitan dengan topik diskusi yang diperlukan penulis.

4. Data yang dihasilkan adalah data yang kualitatif yang dapat memberikan gambaran dan pemahaman atas sikap, persepsi dan perasaan peserta. Hasil ini akan diperoleh melalui pertanyaan terbuka yang memungkinkan dengan cara mereka sendiri. Disini penulis dapat berperan sebagai moderator, pendengar, pengamat dan akhirnya menganalisa secara induktif.

Pertanyaan diajukan dengan cara yang mudah dimengerti oleh peserta, spontan, logis dengan menekankan pemahaman atas proses berpikir dari peserta atas topik yang didiskusikan. 


\subsection{Kualitas Perangkat Lunak ISO 9126}

Kualitas perangkat lunak dapat dinilai melalui ukuran-ukuran dan metode-metode tertentu serta melalui pengujian-pengujian software. Salah satu tolak ukur kualitas perangkat lunak adalah ISO 9126, yang dibuat oleh International Organization for Standardization (ISO) dan International Electrotechnical Commission (IEC). ISO 9126 mendefinisikan kualitas produk perangkat lunak, model, karakteristik mutu, dan metrik terkait yang digunakan untuk mengevaluasi dan menetapkan kualitas sebuah produk software. Standar ISO 9126 telah dikembangkan dalam usaha untuk mengidentifikasi atribut-atribut kunci kualitas untuk perangkat lunak komputer. Faktor kualitas menurut ISO 9126 meliputi enam karakteristik kualitas sebagai berikut[1]:

1. Functionality (Fungsionalitas). Kemampuan perangkat lunak untuk menyediakan fungsi sesuai kebutuhan pengguna, ketika digunakan dalam kondisi tertentu.

2. Reliability (Kehandalan). Kemampuan perangkat lunak untuk mempertahankan tingkat kinerja tertentu, ketika digunakan dalam kondisi tertentu.

3. Usability (Kebergunaan). Kemampuan perangkat lunak untuk dipahami, dipelajari, digunakan, dan menarik bagi pengguna.

4. Efficiency (Efisiensi). Kemampuan perangkat lunak untuk memberikan kinerja yang sesuai dan relatif terhadap jumlah sumber daya yang digunakan pada saat keadaan tersebut.

5. Maintainability (Pemeliharaan). Kemampuan perangkat lunak untuk dimodifikasi. Modifikasi meliputi koreksi, perbaikan atau adaptasi terhadap perubahan lingkungan, persyaratan, dan spesifikasi fungsional.

6. Portability (Portabilitas). Kemampuan perangkat lunak untuk ditransfer dari satu lingkungan ke lingkungan lain.

ISO 9126 adalah standar terhadap kualitas perangkat lunak yang diakui secara internasional. terpenuhinya item-item pada ISO 9126 pada sebuah perangkat lunak tidak serta merta memberikan sertifikat ISO terhadap perangkat lunak tersebut karena standar ISO juga harus dipenuhi dari sisi manajemen pembuat perangkat lunak tersebut, dengan kata lain jika manajemennya tidak memenuhi standar ISO maka hasil kerjanya pun tidak dapat diberikan sertifikat standar ISO.

\subsection{Kerangka Konsep Penelitian}

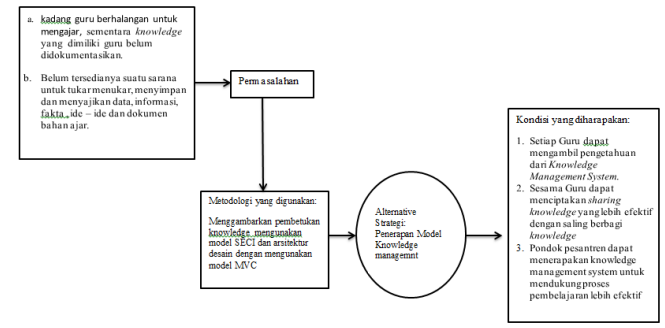

Gambar 3. Kerangka Konsep pemikiran
Kerangka berpikir ini akan dimulai dengan adanya melihat kondisi/keadaan objek yang diteliti saat ini dengan cara melakkukan proses wawancara awal. Kemudian menentukan permasalahan yang terjadi saat ini. Langkah selanjutnya adalah menentukan metodologi penelitian yang akan digunakan, kemudian membuat model knowledge management system yang sesuai. Setelah model knowledge management system sudah didapat, maka barulah dibuatkan prototipe knowledge management system-nya. Langkah terakhir adalah melakukan proses pengujian terhadap prototipe tersebut apakah sudah sesuai dengan kondisi yang diharapkan.

Berdasarkan kerangka konsep yang telah dikemukakan maka pernyataan penelitian ini dapat dirumuskan diduga bahwa dengan model SECI dan Desain MVC dapat menjadi solusi untuk memenuhi kebutuhan knowledge management system dalam mendukung proses pembelajaran di MA Madinantunnajah pada Pondok Pesantren Madinatunnajah.

\section{METODOLOGI PENELITIAN}

Penelitian ini menggunakan metode penelitian Deskriptif Kualitatif dengan metode studi kasus yang bertujuan untuk mendapatkan gambaran yang lebih mendalam dan lengkap dari objek yang akan diteliti. Data atau informasi yang diperoleh pada penelitian ini berasal dari data primer dan data sekunder. Untuk data primer, teknik pengumpulan data dilakukan dengan wawancara dan observasi lapangan. Data dan informasi yang diperoleh melalui studi pustaka bersifat sekunder yaitu data yang diperoleh melalui studi literatur, tulisan ilmiah dan tinjauan studi.

\subsection{Langkah Penelitian}

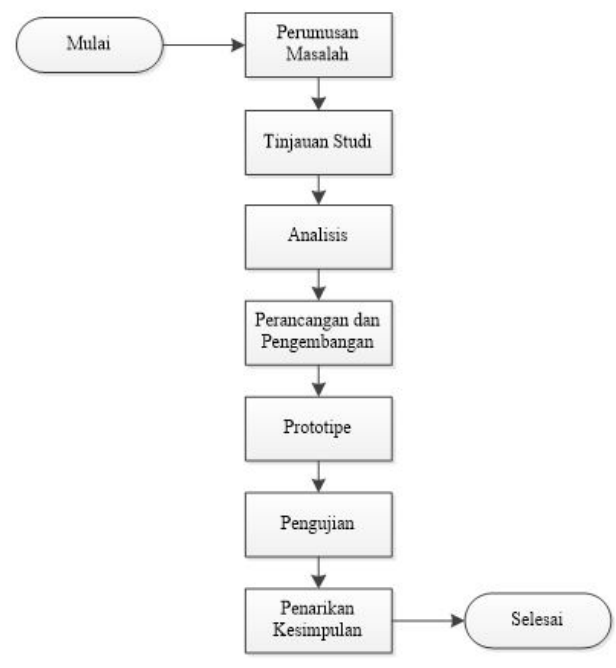

Gambar 4. Langkah Penelitian

Langkah awal dari penelitian ini adalah dengan merumuskan masalah yang terdapat pada Pondok Pesantren dengan melakukan wawancara langsung kepada beberapa guru untuk mendapatkan gambaran 
yang jelas akan keadaan organisasi. hasil dari langkah ini adalah rumusan permasalahan. Selanjutnya Tinjauan studi ini dilakukan untuk mendapatkan teori knowledge management yang terkait dengan rumusan permasalahan. Metode yang dilakukan penulis adalah dengan membaca berbagai referensi terkait knowledge management. Hasil dari langkah ini adalah literatur yang terkait dengan perumusan masalah. Kemudian pada tahap analisis dimana tahap ini dilakukan analisa dan perumusan masalah agar mendapatkan pemecahan masalah. analisis pembentukan knowledge dengan model SECI dan Desain MVC agar dapat mengetahui knowledge yang diperoleh dari tahapan socialization, Internalization, Externalization, dan Combination. untuk pengembangan menganalisa sistem yang akan dibuat untuk menyelesaikan permasalahan yang ada, menganalisa pengguna yang akan menggunakan sistem baru. Selnjutnya dilakukan perancangan sistem menggunakan pendekatan desain MVC dengan menggunakan Unified Modeling Languange (UML). UML adalah sebuah bahasa yang berdasarkan grafik/gambar untuk memvisualisasi dan membangun sebuah sistem pengembangan perangkat lunak berorientasi objek. Pada langkah ini membuat prototipe Knowledge Management System dengan pendekatan model SECI dan Desain MVC yang sesuai dengan kebutuhan di MA Madinatunnajah pada Pondok Pesantren Madinatunnajah. Langkah selanjutnya adalah melakukan pengujian validasi dengan FGD dan pengujian kualitas terhadap protoipe dengan mengadopsi ISO 9126. pengujian yang dilakukan adalah dengan mencoba melakukan proses-proses knowledge management yang didukung oleh prototipe knowledge management system ini. Hasil dari proses ini adalah model knowledge management system yang sudah dites dan dapat diusulkan kepada Pondok Pesantren Madinatunnajah. Terakhir dari penelitian ini makan akan ditarik kesimpulan secara umum sebagai hasil penelitian dan akan menyatakan jawaban terhadap pertanyaan penelitian yang tertuang pada rumusan masalah.

\section{PEMBAHASAN HASIL PENELITIAN}

\subsection{Analisis Kegiatan Organisasi}

Tabel 1. Analisa Kegiatan Guru

\begin{tabular}{ll}
\hline NO & Kegiatan Guru \\
\hline & Melaksanakan rencana pembelajaran \\
& pada suatu/ atau kelompok mata \\
1 & pelajaran tertentu yang mencakup \\
& setandar kompetensi( silabus).
\end{tabular}
pembelajaran (RPP) pada awal tahun atau awal semester.

Guru membuat KKM (ketuntasan

3 kriteria minimum) dalam menentukan ketuntasan materi dan nilai minimum dari suatu mata pelajaran mengajar di kelas

$5 \quad$ Pembuatan soal ujian akhir

Pembuatan tugas tambahan kepada

6 siswa sesuai mata pelajaran yang di ampu

7 Rapat kerja evaluasi proses pembelajaran setiap minggu

8 Pembuatan program tahunan setiap mata pelajaran untuk setiap kelas Membuat modul mata pelajaran sesuai yg mata pelajaran diajarkan

10 Mengevaluasi hasil belajar siswa secara lisan atau tulisan

11 Meberikan arahan arahan pola belajar yang baik

12 Menyusun tata tertib terkait kegiatan belajar mengajar di kelas

13 Mengikuti diklat kurikulum

\section{Analisis Kebutuhan Knowledge}

Untuk mengetahui kebutuhan knowledge yang ada pada MA madinatunnajah, maka harus dilakuakan adalah mengetahui kebutuhan knowledge yang ada. Adapun kbutuhan data, informasi dan knowledge dijelaskan sebagai berikut.

Tabel 2. Analisa kebutuhan Knowledge

\begin{tabular}{|c|c|}
\hline $\mathrm{NO}$ & Knowledge \\
\hline 1 & $\begin{array}{l}\text { Knowledge dalam membuat rencana } \\
\text { pembelajaran pada suatu/ atau } \\
\text { kelompok mata pelajaran tertentu } \\
\text { yang mencakup setandar kompetensi ( } \\
\text { silabus). }\end{array}$ \\
\hline 2 & $\begin{array}{l}\text { Knowledge panduan dalam membuat } \\
\text { rencana pelaksanaan pembelajaran } \\
\text { (RPP) pada awal tahun atau awal } \\
\text { semester. }\end{array}$ \\
\hline 3 & $\begin{array}{l}\text { Knowledge panduan dalam membuat } \\
\text { KKM (ketuntasan kriteria minimum) } \\
\text { dalam menentukan ketuntasan materi } \\
\text { dan nilai minimum dari suatu mata } \\
\text { pelajaran }\end{array}$ \\
\hline 4 & $\begin{array}{lll}\text { Knowledge } & \text { dalam } & \text { proses } \\
\text { melaksanakan } & \text { kegiatan } & \text { belajar } \\
\text { mengajar di kelas } & & \end{array}$ \\
\hline 5 & $\begin{array}{l}\text { Knowledge prosedur dalam membuat } \\
\text { soal ujian akhir }\end{array}$ \\
\hline 6 & $\begin{array}{l}\text { Knowledge dalam membuatan tugas } \\
\text { tambahan kepada siswa sesuai mata } \\
\text { pelajaran yang di ampu }\end{array}$ \\
\hline 7 & $\begin{array}{l}\text { Knowledge Rapat kerja evaluasi } \\
\text { proses pembelajaran setiap minggu }\end{array}$ \\
\hline 8 & $\begin{array}{l}\text { Knowledge dalam membuat program } \\
\text { tahunan }\end{array}$ \\
\hline 9 & $\begin{array}{l}\text { Knowledge dalam membuat modul } \\
\text { mata pelajaran }\end{array}$ \\
\hline 10 & $\begin{array}{l}\text { Knowledge prosedur mengevaluasi } \\
\text { hasil belajar siswa secara lisan atau } \\
\text { tulisan }\end{array}$ \\
\hline 11 & knowledge arahan arahan pola belajar \\
\hline
\end{tabular}




\author{
yang baik \\ 12 knowledge tata tertib terkait kegiatan \\ belajar mengajar di kelas \\ 13 Knowledge kegiatan diklat kurikulum
}

\subsection{Analisis Skenario Knowledge Management System}

Untuk merumuskan sebuah knowledge pada sistem ini perlu dilakukan daur dari proses knowledge management yang terdiri dari 4 (empat) proses yang sesuai dengan model SECI Nonaka. Berikut ini adalah hubungan antara membuat dan merumuskan sebuah knowledge.

\begin{tabular}{|c|c|}
\hline $\begin{array}{l}\text { Socialization } \\
\text { (Tacit-Tacit) } \\
\text { - Berbagi } \\
\text { Pengalaman } \\
\text { mengajar }\end{array}$ & $\begin{array}{l}\text { Externalization } \\
\text { (Tacit-Explicit) } \\
\text { - Penyusunan } \\
\text { bahan ajar }\end{array}$ \\
\hline $\begin{array}{l}\text { Internalization } \\
\text { (Explicit-Tacit) } \\
\text { - Raker (Rapat } \\
\text { Kerja) }\end{array}$ & $\begin{array}{l}\text { Combination } \\
\text { (Explicit-Explicit) } \\
\text { - Berbagi } \\
\text { (sharing) bahan } \\
\text { ajar }\end{array}$ \\
\hline
\end{tabular}

Gambar 5. Model SECI di MA Madinatunnajah

Penjelasan :

\section{Socialization}

Pada tahap ini guru-guru sering melakukan berbagi pengalaman mengajar (sharing) kepada guru-guru lain atau guru baru agar memperoleh pengalaman dan pengetahuan yang baru.

\section{Externalization}

Pada tahap ini dilakukan berkaitan dengan bahan ajar guru di MA Madinatunnajah adalah dengan melakukan pelatihan KKM untuk guru. Pelatihan KKM ini sebagai sarana agar guru-guru memperoleh pengetahuan lebih dan mengembangkan dalam menyusun bahan pengajaran. Pelatihan ini diadakan oleh Depdiknas pusat, evaluasi dari pelatihan ini adalah membuat bahan pengajaran sesuai dengan KKM terbaru.

\section{Internalization}

Pada tahap ini setiap hari Jumat setelah selesai mengajar pihak sekolah akan melakukan rapat kerja (Raker) membahas mengenai pengajaran dan bahan ajar yang harus sesuai dengan KKM terbaru. Pada rapat kerja dilakukan evaluasi pengajaran untuk mengetahui kendala - kendala yang terjadi. Selain raker pelatihan bulanan juga diadakan yang mana guru-guru melakukan bedah buku yang berkaitan dengan bahan pengajaran guna memperoleh dan menambah pengetahuan bagi guru-guru yang lain.

\section{Combination}

Pada tahap ini guru-guru kadang saling berbagi bahan ajar yg berupa soft file kepada guru-guru lain

atau guru baru, agar dapat disusun menjadi sebuah bahan ajar yang baru sesuai dengan KKM terbaru.

Dari hasil analisa 4 (empat) tahapan diatas maka dapat diketahui kebutuhan-kebutuhan yang diperlukan dalam aplikasi KMS yaitu sebagai berikut :

Tabel 3. Analisis Model SECI Di MA Madinatunnajah

\begin{tabular}{c}
\hline Proses \\
Sosialisasi (Tacit $>$ \\
Tacit)
\end{tabular}

\section{Kegiatan}

1. Knowledge dalam proses melaksanakan kegiatan belajar mengajar di kelas

2. Knowledge Rapat kerja evaluasi proses pembelajaran setiap minggu.

3. knowledge arahan arahan pola belajar yang baik

4. knowledge tata tertib terkait kegiatan belajar mengajar di kelas

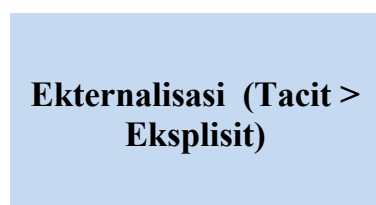

1. Knowledge dalam membuat rencana pembelajaran pada suatu/ atau kelompok mata pelajaran tertentu yang mencakup setandar kompetensi ( silabus).

2. Knowledge dalam membuat rencana pelaksanaan pembelajaran (RPP) pada awal tahun atau awal semester.

3. Knowledge dalam membuat tugas tambahan kepada siswa sesuai mata pelajaran yang di ampu

\section{Kombinasi (Eksplisit $>$ Eksplisit)}

1. Knowledge dalam membuat program tahunan.

2. Knowledge prosedur dalam membuat soal ujian akhir.

3. Knowledge prosedur mengevaluasi hasil belajar siswa secara lisan atau tulisan

\section{Intenalisasi (Eksplisit $>$ Tacit)}

1. Knowledge dalam membuat modul mata pelajaran.

2. Knowledge dalam membuat
KKM (ketuntasan kriteria
minimum) dalam menentukan
ketuntasan materi dan nilai
minimum dari suatu mata pelajaran
3. Knowledge kegiatan diklat
kurikulum

Berikut adalah beberapa aksi yang dapat digunakan pada teknologi yang mendukung proses knowledge management. 
Tabel 4. Kegiatan Pada Teknologi KMS

\begin{tabular}{llll}
\hline No. & KM Tools & \multicolumn{2}{l}{ Kegiatan } \\
\hline 1. & $\begin{array}{l}\text { Diskusi } \\
\text { Elektronik } \\
\text { (Forum) }\end{array}$ & - & Mencari topik \\
& & - & Membalas topik \\
2. & $\begin{array}{l}\text { Modul } \\
\text { Manajemen } \\
\text { Dokumen }\end{array}$ & - & Unggah dokumen \\
& & - & Unduh dokumen \\
& &
\end{tabular}

Untuk mengatur hak akses terhadap penggunaan aplikasi ini maka ditambahkan fitur tambahan yaitu menu user management sebagai menu yang berfungsi untuk mengontrol akses terhadap fasilitas-fasilitas yang ada. hanya yang berstatus admin/pakar saja yang mempunyai akses penuh dalam sistem ini.

\subsection{Analisis Kebutuhan Fungsional Knowledge Management System}

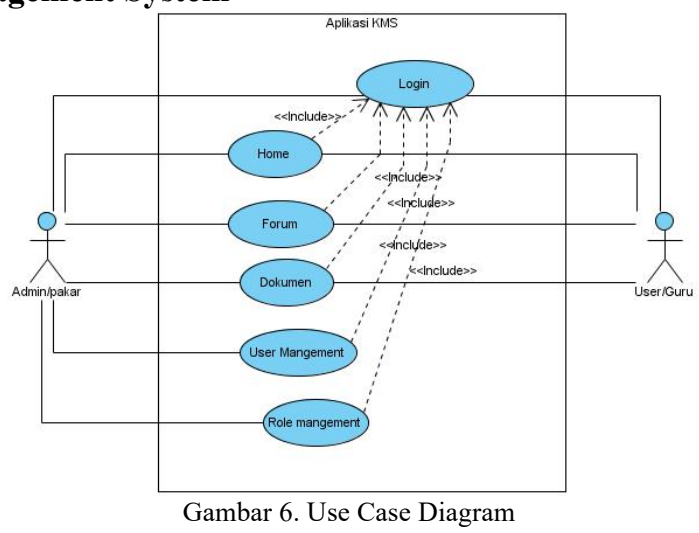

Pada diagram diatas menjelaskan bahwa admin dapat melakukan kebutuhan fungsional seperti berikut :

1. Admin/User terlebih dahulu melakukan login.

2. Setelah berhasil melakukan login, terdapat beberapa pilihan menu yaitu menu user management dimana admin dapat mengelola user yang ada.

3. Menu Forum, admin, dapat melakukan diskusi seperti yang dilakukan oleh mahasiswa dan dosen untuk mengetahui dan menanggapi pertanyaanpertanyaan. Sedangkan mahasiswa dan dosen selain dapat melakukan forum diskusi, juga dapat menambah forum atau pembahasan baru.

4. Menu dokumen, dimana admin dan user dapat mencari, mengunduh dan melihat materi pengajaran yang telah diunggah guru,

\subsection{Analisis Kebutuhan Non-Fungsional Knowledge Management System}

Tahap berikutnya adalah menganalisis kebutuhan nonfungsional dari sistem yang akan dibangun. Tahap ini mengacu pada kinerja pada sebuah sistem maupun kemudahan dalam penggunaannya. Berikut ini adalah kebutuhan nonfungsional pada sistem yaitu :
1. Kebutuhan Operasional : Aplikasi KMS ini bisa dioperasikan pada sistem operasi Microsoft Windows.

2. Kebutuhan Keamanan (Security) : Aplikasi KMS bisa diakses oleh pengguna yang memiliki hak akses. Pengguna pada aplikasi ini adalah dosen dan mahasiswa yang mengajar di STMIK Cikarang. Sistem keamanan pada aplikasi KMS ini adalah tersedianya login yang dilengkapi password.

3. Performa : Aplikasi KMS dapat menampung bahan ajar dalam jumlah yang besar dan dapat diakses oleh user secara bersamaan.

4. Kemudahan Pengguna : Aplikasi KMS seharusnya mudah digunakan dan mudah dipelajari, selain itu aplikasi ini seharusnya memiliki user interface yang menarik agar pengguna nyaman menggunakannya.

5. Panduan Penggunaan : Aplikasi KMS menyediakan panduan mengenai cara dan penjelasan penggunaan masing-masing fungsi yang tersedia dalam aplikasi ini.

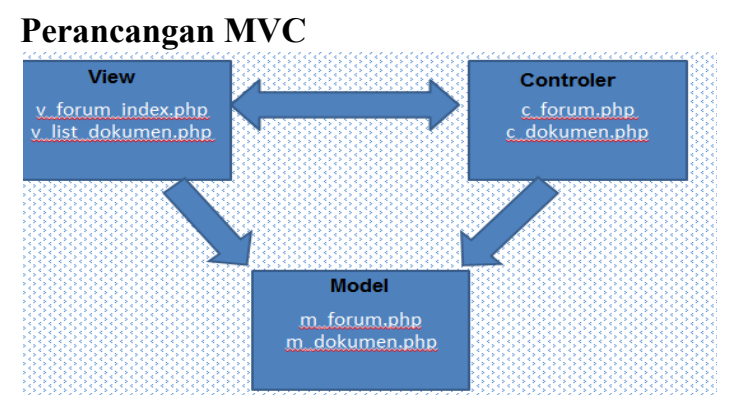

Gambar 4.3 Rancangan MVC

\subsection{Tampilan Prototipe}

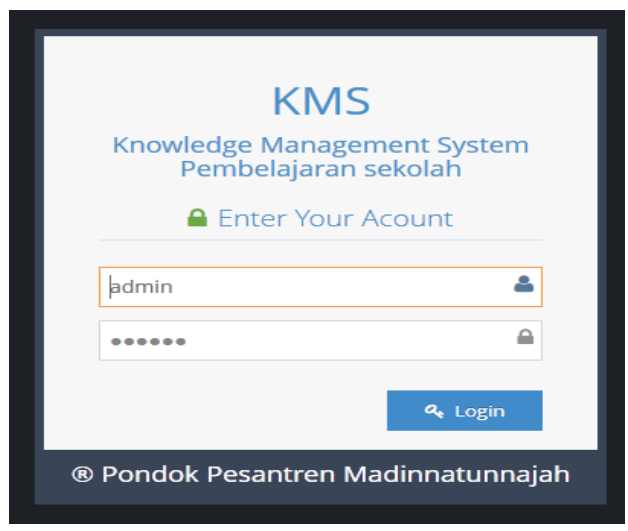

Gambar 4.4 Form login

Pengujian Prototipe Knowledge Management System

Pengujian Validasi

Kegiatan Focus Group Discussion dilaksanakan di ruang kelas d MA madintunnajah pada tanggal 30 juli 2015 pukul $15.00-16.00$ WIB. Dihadiri oleh 6 peserta sebagai responden, 5 responden tersebut adalah guru dan 1 respondennya adalah wakil kepala sekolah. Memulai diskusi, peneliti melakukan presentasi dan demo aplikasi yang sudah dirancang. Peneliti 
menjelaskan setiap fungsi yang ada berdasarkan instrumen yang sudah disiapkan. Setelah responden menyimak penjelasan peneliti dan mengetahui cara penggunaan aplikasi, responden diperkenankan untuk memberikan tanggapan dan persetujuan melalui form yang sudah disiapkan peneliti. Formulir pengujian validasi dengan FGD disertakan dalam Lampiran.

\section{Pengujian Kualitas}

Hasil pengujian kualitas terdiri dari pengujian kualitas masing-masing aspek yang mengadopsi empat karakteristik ISO 9126 yakni Functionality, Reliability, Usability, Efficiency. Rumus untuk mengukur kualitas software menurut ISO 9126 berdasarkan jawaban responden sebagai berikut :

\section{$\%$ Skor Aktual $=$ Skor aktual $\times 100 \%$ \\ Skor Ideal}

Hasil Pengujian :

Tabel 5. Hasil Pengujian berdasarkan 4 aspek dari ISO 9126

\begin{tabular}{ccccl}
\hline Aspek & $\begin{array}{c}\text { Skor } \\
\text { Aktual }\end{array}$ & $\begin{array}{c}\text { Skor } \\
\text { Ideal }\end{array}$ & $\begin{array}{c}\text { \%Skor } \\
\text { Aktual }\end{array}$ & \multicolumn{1}{c}{ Kriteria } \\
\hline Functionality & 664 & 800 & $83 \%$ & Baik \\
Reliability & 242 & 300 & $80,66 \%$ & Baik \\
Usability & 337 & 400 & $84,25 \%$ & Sangat Baik \\
Effeciency & 259 & 300 & $86,33 \%$ & Sangat Baik \\
Total & $\mathbf{1 5 0 3}$ & $\mathbf{1 8 0 0}$ & $\mathbf{8 3 , 4 4 \%}$ & Baik \\
\hline
\end{tabular}

Berdasarkan tabel di atas dapat disimpulkan bahwa tingkat kualitas perangkat lunak knowledge management system untuk mendukung proses pemebelajaran pada pondok pesantren madinatunnajah secara keseluruhan dalam kriteria Baik dengan persentase 83,44 \%. Aspek kualitas tertinggi berdasarkan tanggapan responden adalah dari aspek effeciency dengan persentase 86,33 \% selanjutnya aspek usability dengan persentase $84,25 \%$, aspek reliability dengan persentase $80,66 \%$, sedangkan aspek functionality dengan kualitas sebesar $83 \%$. Kesimpulan berdasarkan hasil pengujian dibuktikan bahwa kualitas perangkat lunak knowledge management system yang dihasilkan jika diukur dengan mengadopsi pengujian kualitas perangkat lunak model ISO 9126 dalam kriteria Baik dengan persentase tanggapan responden sebesar $83,44 \%$.

\section{KESIMPULAN}

Berdasarkan analisis dan kajian yang dilakukan di Pondok pesantren Madinatunnajah dapat ditarik kesimpulan bahwa pengembangan knowledge management system untuk mendukung proses pembelajaran dapat diterapkan di MA madinatunnajah. Dengan prototipe yang dirancang menggunakan konsep knowledge management system antara lain externalization, socialication, combination, internalization menghasilkan fasilitas yang disediakan dalam dalam bentuk diskusi elektronik (menu forum), pengelolaan dokumen (menu manajemen dokumen), dan pengelolaan user (menu manajemen user) akan mampu menjadi solusi untuk memenuhi kebutuhan knowledge management system dalam mendukung proses pembelajaran di MA Madinantunnajah pada Pondok Pesantren Madinatunnajah, berdasarkan hasil pengujian membuktikan bahwa kualitas perangkat lunak knowledge management system yang dihasilkan jika diukur dengan mengadopsi 4 karakteristik pengujian kualitas perangkat lunak model ISO 9126 dalam kriteria Baik dengan persentase tanggapan responden sebesar $83,44 \%$.

\section{DAFTAR PUSTAKA}

[1] Al-Qutaish, Rafa, E. 2010, “Quality Models in Software Engineering Literature: An Analytical and Comparative Study." Journal of American Science 6: 166-175

[2] Becerra-Fernandez, Irma, Gonzales, et.al, Rajiv. 2004, Knowledge Management : Challenges, Solustions and Technologies, Pearson/Prentice Hall.

[3] Burbeck, Steven. 1992, Application Programmings in Smaltalk's 80 TM: How To Use MVC, http://stwww.cs.illinois.edu/users/smarch/st-docs/mvc.html (Diakses Selasa, 16 Juni 2015).

[4] Butler, Heavin, \& O'donovan, 2007, A Theoretical Model and Framework for Understanding Knowledge Management System Implementation, Western Road, Cork City : University College Cork.

[5] Dalkir, Kimizet. Knowledge Management in Theory And Practice. Oxford:Elseiver Inc ,2005

[6] Davidson, Carl, Voss, Phillip. 2003, Knowledge Management An Introduction to Creating competitive advantage from intellectual capital, Vision Book.

[7] Deacon, Jhon. 2009. Model View Controller Architecture, http://www.battersealocksmith.co.uk/briefings/MVC.pdf (diakses Rabu, 17 Juni 2015).

[8] Driyani, Dewi 2014, Prototipe Materi ajar SMA Berbasis Knowledge Management System Dengan SoftwareDevelopment"CMS Lokomedia": Studi Kasus Pada SMA Negeri 23 Jakarta, Tesis, Jakarta : Universitas Budi Luhur

[9] Jihan, Hanifah 2014, Prototipe Knowledge Management System Untuk Mendukung Proses Belajar Mengajar Di Sekolah Menengah Yuppentek Tangerang, Tesis, Jakarta : Universitas Budi Luhur.

[10] Litosseliti, L, 2003, Using Focus Group Discussion in Researh, Continum London.

[11] Susanto, Arif 2013, Prototif Sistem E-learning Berbasis knowledge Management: Study kasus Paud Nur Rahma Tanjung, Tesis, Jakarta : Universitas Budi Luhur.

[12] Widodo, Wahyu, 2015, Membangun Web Super Cepat Dengan CodeIgniter GroceryCRUD, Kediri: In Wahyu Widodo. 